\title{
Management of Quality Improvement for PAUD (Case Study of PAUD Handayani at Pontianak City)
}

\author{
Siti Ruwaidah ${ }^{1)}$, Wahyudi $^{2)}$, Sukmawati ${ }^{3)}$ \\ ${ }^{1)}$ Universitas Tanjungpura, Pontianak, Indonesia \\ E-mail: sitiruwaidahalfikri40@gmail.com \\ ${ }^{2)}$ Universitas Tanjungpura, Pontianak, Indonesia \\ E-mail: wyudi_fkip@yahoo.com \\ ${ }^{3)}$ Universitas Tanjungpura, Pontianak, Indonesia \\ E-mail: sukmawati@fkip.untan.ac.id
}

\begin{abstract}
The quality of education is a benchmark in assessing the success of the school in creating qualified students. It is appropriate if the school or institution can maintain and improve the quality of its education. Improving the quality of education is influenced by many factors, such as the leadership of the manager, the professionalism of the teacher, and the support of the teaching and education personnel in the institution. The purpose of this study was to obtain information about improving the quality of PAUD that focused on how planning, management, evaluation, inhibiting and supporting factors in the implementation of Handayani PAUD quality improvement, as well as efforts made to overcome the obstacles found in applying quality improvement planning. This research uses descriptive qualitative method. Data collection procedure techniques used are field research techniques while the methods used are observation, interviews, and documentation. Subjects in this study were managers, teachers, and education personnel in Handayani PAUD. The results of this study indicate that: (1) improving the quality of institutions can occur if there are plans and programs that are prepared and disseminated by joint managers of educators and education personnel and related parties, (2) management of quality improvement needs the support of all parties in the institution, (3) the evaluation of the improvement of the quality of education by the manager by supervising it periodically and continuously, and the manager should also involve the role of the supervisor to help supervise the program management in the institution, (4) the commitment of all parties in the institution is a supporting factor while less optimal evaluation from the manager, educational background of educators that are not appropriate and the professionalism of educators in carrying out the learning process is one of the inhibiting factors, and (5) the efforts made to overcome obstacles are by involving educators and education personnel in workshops or training mbingan and motivation, as well as planning to form a parenting program with parents of students around the institution's environment because the quality of education will increase and be carried out well with joint efforts, maximum control and evaluation of managers and related parties.
\end{abstract}

Keywords: Management; Quality Improvement; Case Study

\section{INTRODUCTION}

Early childhood for children is the golden age, which only comes once in a lifetime and cannot be repeated. At that time the child was in a sensitive where the child was especially easy to accept as a stimulus from the environment. Even around $50 \%$ of adult intelligence had occurred when they were four years old according to Nova Ardy Wiyani (2014: 7).
It shows that what a loss is a family, society, and nation if why is the important period that takes place in early childhood because growth and intelligence development that takes place optimally is very influential on later life.

Humans need knowledge in their lives. The knowledge can be obtained through the education process. Education can shape human character to be a better human being and is useful for others, faithful and devoted and responsible. Education in Law No. 
20 of 2003 (Article 3) concerning National Education System aims to develop the potential of students to be faithful and devoted to God Almighty, noble, healthy, knowledgeable, capable, creative, independent, and a democratic and responsible citizen.

Education can be obtained from an early age or childhood. At this age, human character can be formed and created in accordance with the education obtained. One of the goals of education is that it can create safety and happiness for humanity, in accordance with Ki Hadjar Dewantara's statement in the book Sita Acetylena (2018: 111) in education and the process of forming positive language character is an important and appropriate tool for character building that guides all forces the nature that exists in children, so that they as human beings and as members of society can achieve the highest salvation and happiness. According to Suyadi (2013: 5) character education is the universal values of human behavior which encompasses all activities of life, both those related to God, oneself, fellow human beings and the environment manifested in thoughts, attitudes, feelings, words, and deeds based on norms of religion, law, karma, culture, and customs. And also stated that he also wanted a) to place students as centers of education, b) to view education as a process that is thus dynamic, and c) to prioritize the balance between creativity, taste, and intention in children.

The quality of education is a benchmark in assessing the success of the school in creating qualified students. Schools can be said to be of good quality if there is a good learning process in the school, and has school institutions or institutions that are able to handle and be responsible for the learning outcomes of their students.

The meaning of improving the quality of education is that not only can educate children to gain knowledge, but also can develop children's knowledge comprehensively. Improving the quality of education can also provide hope for students to get a more decent life in the future. According to Edward Sallis (in Jasuri, 2014: 15) said, Total Quality Management (TQM) is a philosophy of continuous improvement, which can provide a set of practical tools to every educational institution in meeting the needs, desires, expectations of its customers, currently and for the future.

Every child has the right to get an education from an early age; the most important is from the family and school scope as a continuation. The potential of children will develop very rapidly, namely between the ages of 0 to 6 years, that's where the importance of early age education is because the age is the golden age period. Education in schools for early childhood provides many opportunities to develop various activities involving fine and gross motor physical, intelligence, socio-emotional language, and communication, in accordance with the stages of development of early childhood. According to Maimunah Hasan (2012: 7). Early Childhood Education (PAUD) is the implementation of education that focuses on laying the foundation in several directions including 1) physical growth and development (fine and rough motor coordination). 2) intelligence (thinking power, creativity, emotional intelligence, spiritual intelligence) 3) socioemotional (attitude and behavior, religion) language and communication, which is adapted to the uniqueness and developmental stages of early childhood.

Whereas in Law no. 20 of 2003 concerning the national education system stated that PAUD is a coaching effort aimed at children from birth to 6 years of age which is carried out through the provision of educational stimuli to assist physical and spiritual growth and development so that children have readiness to enter further education.

From the two above definitions, it was concluded that the purpose of early childhood education helps the child's physical and spiritual growth and development so that they have readiness to enter further education.

The high expectations of the people with the existence of early education can be seen from the enthusiasm of parents in sending their children to school. It cannot be separated from the teacher who has given birth to a quality successor. Teachers are considered good in teaching when the teacher is able to master the class and is skilled in attracting students' interest in learning well. According to Jamal Ma'mar Asmani (2015: 13), PAUD teachers must be dynamic and revitalized to their full potential in order to be able to carry out a large task of delivering early childhood children to recognize the greatest potential they possess and ways to hone and develop consistently and continuously.

In relation to efforts to improve the quality of education, the school pays attention to the mandate of the law no. 20 of 2003 concerning the national education system, law no.14 of 2005 concerning teachers and lecturers. Government Regulation no. 19 of 2005 concerning national standards of education which means that its quality education school is a school that meets minimum standards, namely, content standards, process standards, SKL or STPPA for PAUD, standards of educators and education personnel, facilities and infrastructure standards, management standards and assessment standards, Maswardi and Yulianingsih (2011: 4).

There are several things that become a reference for improving the quality or quality of PAUD. Among them are the following: a) there are minimum standards before the community or foundation establishes PAUD institutions, b) educators who will teach in PAUD should be trained in at least 2 months, so that they can carry out their duties to the maximum; c) PAUD educators should participate in PKB (Continuing Professionalism) 
activities, d) optimize the role of Himpaudi \& PAUD Forum, in developing the potential of its members; e) conduct comparative studies, f) teachers increase reading likes because the knowledge of PAUD is very broad, especially learning unique children requires a lot of knowledge; g) teachers or educators must go to school again; h) allocation of funds from the Regional Government to improve the quality of PAUD educators in their respective regions; and i) growing the spirit of researching for the teachers because of the complexity of the child's problems, then at least educators must be fond of researching if there are problems that feel blocked.

In the ideal PAUD manager according to candy reference no. 137 of 2014 Article 25 states (1) Academic Qualifications of PAUD Teachers: a. have a four-Diploma (D-IV) diploma in the field of early childhood education obtained from an accredited study program, or have a relevant education or psychology diploma of four (D-IV) or bachelor (SI) obtained from the Professional program Teacher (PPG) PAUD from an accredited college. (2) Competency of PAUD Teachers is developed in a complete manner covering professional personality, and social competencies, as contained in Attachment II which is an integral part of the Minister's regulation.

In the field, there are still many educators in Handayani PAUD who do not have academic qualifications as PAUD educators, but are able to achieve B accreditation category, either playgroup (KB) or Kindergarten (TK) programs. Handayani PAUD is able to implement PAUD quality management to be able to compete in change by developing education programs that can improve the quality of early childhood education (PAUD). Based on the above background, the authors are interested in conducting research in Handayani PAUD which is located on the Selat Panjang road in Siantan Hulu Village, North Pontianak Subdistrict.

\section{RESEARCH METHOD}

\section{Research Approach and Type of Research}

This study uses a qualitative research approach because this research was conducted to obtain data, scientifically for the purpose and usefulness of an ongoing problem, namely the improvement of the quality of Handayani PAUD. This research describes the problems raised based on real facts. The fact is based on specific facts, then examined to solve the problems and then draw general conclusions. Therefore, this study aims to describe the management of improving the quality of education in PAUD Handayani, North Pontianak Subdistrict, Pontianak City.

Research Location
This research was conducted at Handayani PAUD in North Pontianak Subdistrict, Pontianak City.

\section{Data Sources}

The data needed in this study comes from primary data and secondary data. Primary data is data that is directly given to researchers about the opinions in the management of Handayani PAUD quality improvement that is carried out by managers including, quality improvement planning, procedures performed, how to evaluate management from quality improvement planning, supporting factors and inhibitors of quality improvement, and effort- efforts made to overcome in the process of quality improvement. The data referred to in these secondary sources are existing literature and can assist researchers in completing this research such as managers, educators, accreditation documents, and the data obtained through observation and recording about the general picture in the implementation of quality improvement in Handayani PAUD.

Data Collection Procedure

Data collection techniques are one of the methods used to obtain data/information in research. Data collection techniques used are field research, namely the author plunges directly into the field to obtain the required data, while the methods used are:

a. Observation

b. Interview

Interviews were conducted to managers/principals, educators and education staff in Handayani PAUD Pontianak City with the time that researchers had made with the informants.

c. Documentation

This research uses documentation method to quote and analyze data that has been documented in Handayani PAUD.

Furthermore, through documentation of the data will be obtained accurate information relating to the title of the research on improving the quality of education and school profiles. So it is useful in learning the background and progress that has been achieved so that the document data is supporting and complementary to the primary data obtained from indepth interviews and interviews. To obtain data about the management of Handayani PAUD quality improvement, the researchers tried to be in a situation of blending with managers, educators, and administration in the management of quality improvement in Handayani PAUD Pontianak City.

\section{Types of Data Analysis}

The data analysis process in this study uses interactive model data analysis which consists of three data analysis components, namely data reduction, data display, and Miles and Huberman (in Sugiyono, 2014: 91). The process of these three components is a cycle, where the process of data 
reduction, data presentation, and conclusion drawing are sequential and sequential analysis sequences.

Based on the interactive analysis, the data analysis is carried out with the following steps: a) Researchers come to the research location for interviews, observation, and documentation to collect data related to the research problem. b) Data that has been collected, then reduced, sorted, and systematically clarified to then be presented. c) Data from the presentation is then analyzed, the results of this analysis are then reduced so that the conclusions taken can truly be accounted for. d) After data reduction has been carried out, then the data is presented as a conclusion in the form of descriptive or description which is of course also equipped with supporting data for the perfection of research results.

The data analysis process begins by examining all data available from various sources. According to the data analysis technique used in this study is to use steps as stated by Miles and Huberman in Sugiyono (2014: 91), namely as follows:

1. Data reduction

During the data collection process, all the data produced was collected from the results of documentation studies and observations about the management of quality improvement in Handayani PAUD Pontianak City. The data is then poured in a summary form which contains a brief description of the results of understanding and sharpening the data that has been collected.

Then the collected data is read and understood again. So that the data is done to identify the data entered to be presented based on the research focus. Data selection is done to avoid biases that arise as a result of the complexity of the data that comes out of the focus of the research.

2. Presentation of Data

The data in this study will be presented simply in the form of words, sentences, narratives, if possible according to the data category. Such data presentation is expected to have collected data giving a comprehensive and seemingly simple picture, which ultimately makes it easier for researchers to interpret and use the data to make the right decisions.

The data presented in this study are data relating to the implementation of quality improvement in Handayani PAUD Pontianak City including (1) planning for improving the quality of PAUD Education. (2). management of PAUD quality improvement. (3) evaluation of PAUD quality improvement. (4) things that support and hinder the management of PAUD quality improvement. (5) efforts made to overcome obstacles.

3. Conclusion

The conclusion is the essence of the research findings that describe the last opinions based on previous descriptions or the decisions obtained based on the motive of inductive and deductive thinking. The conclusions made must be relevant and focused on research, research objectives and research findings that have been conducted that have been interpreted and discussed. In accordance with the purpose of the study, to obtain information about the management of quality improvement in PAUD Handayani, Pontianak City. Then the research findings are expected in the form of planning, management, evaluation, inhibiting and supporting factors and how to overcome the obstacles found during the management of quality improvement in Handayani PAUD Pontianak City.

Checking the Validity of Findings

In this study to find the validity of the data using data triangulation techniques. The data triangulation conducted by researchers at PAUD Handayani, Siantan Hilir Village, North Pontianak Subdistrict by a) comparing observational data with data from interviews with the teacher, b) comparing what one teacher said with another teacher, c) comparing the state of perspective a teacher with various opinions of other teachers, d) comparing the results of interviews with the contents of a documentation that has to do with Handayani PAUD. Research Stages

In this study, researchers started with preparation, implementation, and reporting.

1. The preparatory phase starts from January 2018 where it begins with prior permission from the institution, preliminary observation, preparation and stabilization of research proposals through seminars, consultation on research improvements and arranging research permits.

2. The implementation phase includes data collection and data analysis including:

a. Received a research permit from the Dean of FKIP UNTAN Pontianak, then submitted a research letter to the PAUD Handayani Manager of Pontianak City.

b. Researchers met Handayani PAUD Manager and expressed the objectives of the researchers and made an agreement about the time for interviews with informants.

c. Researchers interviewed Managers, Educators, and Education personnel.

d. Research conducts interviews, observations, searches for documents related to research while managing data and analyzing data that has been collected into patterns and consultations.

e. Determine themes, analysis of themes and completeness of consultation data

f. Test the validity of data based on data groups and consultation

g. Draft/report and consultation

h. Prepare research and consultation reports

i. Research test results (thesis exam)

j. Thesis improvement and consultation

k. Report submission

3. Reporting phase 
Furthermore, the administrative staff said that the institution could have adequate facilities and infrastructure, systematic management and financing program that could improve the quality of the institution as expected.

A. Result

\section{RESUlT AND DISCUSSION}

In accordance with the research, focus developed, in this chapter the researcher also presents data and research findings, namely: (1) Planning for improving the quality of PAUD. (2) PAUD quality improvement management. (3) PAUD Quality reminder evaluation, (4) supporting and inhibiting factors faced in implementing PAUD quality improvement, and (5) efforts made to overcome obstacles found in the PAUD quality improvement process.

1. Quality Improvement Planning in Handayani PAUD

a. Interview Results

To improve the quality of the institution, a manager will certainly develop a planning program for his institution. From the interviews that have been conducted by researchers with Handayani PAUD managers, it is known that with regard to the process of teaching and learning activities, the manager has conveyed to the teaching teachers in the institution to be able to prepare the learning tools periodically. Especially for the preparation of $\mathrm{RPPH}$, so that the teacher as much as possible compile it himself by taking into account the classroom conditions and the characteristics of the students faced, and referring to the syllabus and curriculum apply. For this reason, the teacher must be more creative in choosing a learning approach that is in accordance with the characteristics of students in the class he or she receives.

For teaching staff, managers program so that teachers who teach in institutions can have an appropriate educational background. The next program is a program that has been prepared together with the teacher and staff in the institution, namely eight standard programs, some of which are about curriculum, infrastructure, management, and financing.

Information obtained by researchers from administrative staff reveals that the programs prepared by the manager for both teachers who teach in the institution, as well as the administrative staff themselves have been adjusted to their respective job desk. For administrative staff themselves, for example, so that matters related to institutional management can be arranged neatly and regularly, about data on educators, students, inventory of institutions, and matters relating to the administration of other institutions.
It was also said by the teacher and companion who taught in the institution that the manager had conveyed the program that had been planned by the manager in relation to improving the quality of the institution in the division of tasks and employee discipline at the beginning of the school year.

From the interviews that have been conducted with several teachers, researchers can conclude the things that have been programmed to support the improvement of the quality of the institution are, curriculum development, preparing RPPH in accordance with the syllabus, completing learning tools, choosing the right learning method for students, using various the types of media that already exist, and make the necessary media themselves that the institution does not yet have. The use of varied learning methods and media is very important and needs to be considered so that students can develop optimally in accordance with their interests and needs.

\section{b. Documentation Results}

Based on the results of interviews and documentation it can be concluded that the Handayani PAUD quality improvement planning in Pontianak city is based on the preparation of an annual work program that has been made by the institution and evaluated to see how far it is implemented and what constraints it faces.

2. Management Done to Improve School Quality

a. Interview Results

PAUD Handayani's manager said that improving the quality of institutions does not always mean obtaining high grades or achievements. Improving the quality of institutions can also be seen from the changes and development of students, both character and academic, which are getting better.

The implementation of this quality improvement certainly cannot be done by the school itself, but also requires the support of parents of students. Therefore, the manager has also socialized the wishes of the school to continue to improve the quality of the institution in a meeting attended by committees, parents of students, and PAUD Handayani educators and education staff which was held at the beginning of the school year. In addition, the programs owned by the school have also been outlined in the annual program of the institution to facilitate managers in their implementation and evaluation. 
Regarding improving academic quality, institutions have made several efforts. In this case, the participation of educators and students is needed. Managers always give motivation to educators to keep improving themselves, including in training, and competitions.

In line with what has been conveyed by the manager, some teachers who have been asked for information about the steps taken by the manager to improve the achievements of the institution, one of which is to motivate the teachers to become outstanding teachers. The manager holds a meeting on discipline, provides guidance when the teacher will take part in training or competition. And in terms of improving student achievement, teachers are also encouraged to develop children as best they can, and make it an additional learning program.

For administrative staff, the steps that have been taken to compile institutional data regularly, to facilitate reporting and provide administrative information when needed. In terms of management, administrative staff always report the final state of the institution at the end of each month, as well as the financing documents that have been recorded. In addition, the administrative staff is also responsible for the assets of the institution. Therefore, whenever an institution's assets have been used, they will be trimmed or returned to their original place so that they will not be easily damaged and maintained. b. Observation Results

Observations made by researchers when several times were present in the process of learning activities. Researchers see first hand the ongoing activities. That educators in PAUD Handayani carry out learning activities in accordance with the planning that has been made with the learning approach in accordance with the achievement of the child's age development. In addition, there is the use of media and provides a game that supports learning. Hopefully, all students are focused on playing activities while learning to learn while playing.

c. Documentation Results

Based on the documentation, it can be seen that Handayani PAUD in management improves the quality of PAUD through carrying out all of the plans listed in the annual program. Which starts with the socialization activities and what steps must be carried out. The results of the documentation in appendix 16 about curriculum implementation.

Based on the results of interviews and documentation it can be concluded that the management of the quality improvement of Handayani PAUD in Pontianak City is carried out by the educators and administrative staff.
3. Management evaluation of Quality Improvement Planning.

a. Interview Results

Some things that are done to evaluate the management of quality improvement planning in Handayani PAUD are that the manager periodically supervises, i.e., at least two times a year. Then the teacher who observes the results of the assessment of the child's development, both the development of its characteristics and academic development. Assessment conducted by the teacher is carried out during the KBM process and at the end of learning. Evaluation and assessment are important tasks of educators.

One teacher also said that an evaluation of improving the quality of institutions could be obtained through dialogue with the surrounding community, especially parents. With this, the institution can get their views and opinions about the development of the quality of the institution from time to time.

b. Documentation Results

Based on the declaration, it can be seen that Handayani PAUD Pontianak City has evaluated through supervision of its administrative devices, the process of learning activities and the condition of facilities and infrastructure by inventorying all the items of the institution it owns.

Based on the results of interviews and decommissioning, it can be concluded that management evaluation of Handayani PAUD quality improvement planning through periodic supervision.

4. Supporting Factors and Inhibiting the Quality Improvement of Handayani PAUD

a. Interview Results

In general, the manager said that the supporting factors that enable the implementation of improving the quality of institutions are the presence of educators and education personnel who want to participate in supporting this program. In addition, the institution also has adequate facilities and infrastructure. While the inhibiting factor is the desire of some parents, who want their children to be given calistung material immediately. But educators in Handayani PAUD remain committed to that early childhood education is playing while learning and learning while playing. Because playing is still an important part of early childhood development.

From the information obtained by researchers from teachers and administrative staff, it is known that another inhibiting factor is that the institution does not yet have a teacher with an education degree in PAUD and administrative staff with an appropriate 
educational background. Besides that the teacher also has not used various learning methods. However, the manager still has a positive mind that the teacher and administrative staff in his institution must have the willingness to continue to learn to develop their professional abilities, which can later have an impact on improving the quality of the institution.

For infrastructure facilities, management and financing of institutions have been managed quite well. It's just that there are some institutional facilities that must get routine repairs and maintenance. Another obstacle conveyed by the manager is minimal funding. With students who are predominantly from middle to lower families, the costs set by the institution amount to Rp. 50,000 / month, still considered by some parents of students. However, it does not dampen the desire of PAUD Handayani to continue to be able to develop institutions and educate early childhood in the environment around the institution.

Then the opinion expressed by the teacher about other supporting factors to improve the quality of the institution is the existence of the principal program, adequate institutional facilities, and teachers who are included in training in accordance with their fields. And the inhibiting factor is the lack of media and APE available at the institution. One teacher also added that he felt less creative in utilizing the media and APE that were available at the institution, and this also became one of the obstacles in improving the quality of teaching in the classroom.

Institutional achievements are also supporting factors for quality improvement which are also influenced by the quality of students. Unfortunately, students who will study at this institution do not go through academic selection. It is a challenge for the teachers, so that children who study in Handayani PAUD can have evenly distributed academic abilities, and can get achievements both inside and outside the school.

The latest information about the factors inhibiting and supporting this quality improvement was obtained from the administrative staff stating that a conducive working atmosphere had a positive impact on the performance of employees in the institution. But unfortunately, with an educational background that is not in accordance with the current field of work, he hopes that there will be training on administrative personnel that he can follow. So that his knowledge of administrative science can increase and can give a good influence on his work. And better understand the tasks that will be carried out as administrative staff at PAUD Handayani Pontianak City.

5. Efforts Made by Institutions to Overcome Obstacles Found in the Quality Improvement Planning Process

a. Interview Results

The manager said efforts were made to overcome some of the obstacles faced in improving the quality of education, for example for parents of students who always wanted their children to learn calistung, managers would patiently open themselves and insight with guardians of students and the community. It is also one of the functions and main tasks of an PAUD manager. From this, it can form the closeness between managers and parents so that managers can freely provide understanding and understanding to them.

The manager also wishes to hold a parenting program in his institution. Because with the existence of parenting, managers can manage PAUD programs with the community to find support for ideas, learning resources, and institutional funding. With this activity, parents get knowledge in accordance with the role of parents and what should be done as parents of students. This program will be discussed first with relevant parties in the institution to be planned and implemented in the institution.

For problems with teacher education in institutions that are not appropriate, the manager will always strive to provide reinforcement and motivation to include training or training that can add to the knowledge and insight of the teacher. Although the institution should continue to look for teachers who have the appropriate educational background. The manager also stated that it was not possible if the agency would recruit new educators if he found an HR who had an appropriate educational background.

Based on the statement given by the administrative staff regarding the educational background that is not appropriate, the manager will certainly include administrative staff if there is appropriate training or training. But the manager believes that with the current quality of work, the professional attitude shown by the administrative staff, the tasks assigned to him can be carried out properly and trustworthy.

For APE and media whose numbers are still not in accordance with the number of students, the manager has asked the teacher and administrative staff to maintain the APE and the existing media, so that it is durable and not damaged quickly. While for the addition of the number and variants, the manager will strive gradually to be able to fulfill it by socializing with parents, if possible there are among the parents of students who are willing to provide 
additional media. And adding media purchases and APE in the planned use of the agency's aid budget.

\section{B. Discussion}

After analyzing the results of the research, then the next is to explain the results of the research that has been done. This presentation is a description of the data from the results of direct observation, interviews and document studies at the institution. In this discussion, the researcher will restate the findings data and then study it with theory, or relevant expert opinion.

1. Quality Improvement Planning in Handayani PAUD

In essence, planning is something that is planned what must be done, when to do it, how to do it, and who does it (T. Hani Handoko, 1989: 77) The series of activities that have been planned are then implemented to be realized later. In this regard, the manager at Handayani PAUD institution has also made plans to improve the quality of the institution he leads.

The results of the study describe how a manager acts as manager in the institution he leads. Robbins and Coulter write that "managers engage in planning, establish their goals strategies for achieving those goals, and develop plans to integrate and coordinate activities" (2016: 41). It was also stated that a manager is responsible for planning and arranging things that need to be done by his workers to achieve the stated goals

PAUD Handayani's management has designed the management of the institution, and the program appears in the document about the Work Plan for the Project. The program that has been created is of course compiled through evaluations that have been carried out on the results of program management that have been carried out in the previous school year. This program is then socialized to all staff in the institutions and parents of students through socialization meetings so that all parties can play a joint role to improve the quality of the institution.

For planning quality improvement related to the teaching and learning process, the manager has conveyed that the teacher can prepare the learning tools periodically. Teachers as subjects in doing this learning planning are required to be able to compile various teaching programs in accordance with the approaches and methods to be used (Veithzal Rivai and Sylviana Murni, 2009: 112). Therefore, teachers should also have sufficient knowledge about various approaches and methods of learning. It will greatly affect how the teaching and learning process takes place in the classroom and also the results obtained after the teaching and learning process is complete.

The manager also said that the aspects in RPPH prepared by the teacher should also be prepared based on the curriculum and syllabus that has been set. Quality of education will be achieved if the teacher refers to competency standards that must be mastered, materials, learning resources, appropriate methods and media, and evaluation and programs to determine the next steps. To achieve these goals, Hidayat (in Veithzal Rivai and Sylviana Murni, 2009: 112) states that several things that must be prepared in the planning of teaching are: (1) understanding the curriculum, (2) mastering teaching materials, (3) preparing teaching programs, (4) carrying out teaching programs, and (5) assessing the teaching and results of the teaching and learning process that has been carried out.

The next planning program is to choose the right learning method for students, to use a variety of existing media, and make the necessary media themselves that the institution does not have. The implementation of this program is expected to improve the quality of children's education. Because the use of appropriate methods and media can increase students' interest to be more active and focus on learning.

One of the plans to improve the quality and management of the institution, which empowers the administrative staff to manage and compile matters relating to information and communication technology and administration. In addition, the manager also handed over the management of goods and management of school facilities and infrastructure to administrative staff. With good quality of work and responsibility and a professional attitude, the manager hopes that the administrative staff can carry out management planning to improve the quality of education in their institutions.

2. Management of Quality Improvement Planning in Handayani PAUD

One of the enhancements of the quality of education to produce students with character and achievement. The success of student education is one sign of increasing the quality of institutions. It can be realized by the commitment between the school, students, and parents of students. For this reason, there must be a good relationship between the institution and parents. The first step taken by the manager is to socialize the school program to improve the quality of Handayani PAUD education.

Managers, by providing reinforcement, motivation, participating in training and training, and continuous guidance to educators and education personnel can create a conducive culture and work climate of PAUD institutions. It is in accordance with the managerial competence that must be owned by the manager in accordance with government regulation No. 13 of 2007.

Managers as leaders in institutions also conduct monitoring, supervision, and evaluation of their employees. Not only for its employees, but the manager also acts as a supervisor for every element of the school program. Like the curriculum, 
administration, infrastructure, relations with the community and also finance. The manager's function in the field of supervision is part of the manager's role as an education supervisor as well as a bureaucracy in education management (Mukhneri Mukhtar, 2013: 178).

The manager functions and is responsible for two aspects of management in the school. The first is the aspect of staffing, finance and facilities and infrastructure. In this regard, the manager has given this responsibility to the administrative staff of the institution. Administrative staff regularly compile staffing data regularly, report on financial reports, and maintain and report the condition of damaged institutions and infrastructure and require repairs.

The second aspect is the technical aspects of education, including teaching and learning activities. The manager has done it by arranging programs, such as the division of the teacher's duties, developing the curriculum, and requesting that the teacher prepare and equip the learning lesson. The manager also supervises that is carried out at least once a semester.

The supervision carried out by the manager of the teacher is an obligation and is appropriate to be done as a direct supervisor at school. By supervising, managers can see directly the activities carried out by the teacher in the implementation of learning activities in the classroom. In this supervisory activity, the manager can measure whether the implementation of the learning carried out by the teacher is in accordance with the predetermined standard or measuring instrument. Supervision carried out by the manager is in accordance with the function of the principal as manager and education supervisor in accordance with the manager's ability and commitment that has been made with the teachers who teach in his institution (Mukhneri Mukhtar, 2013: 181).

Improving the quality of education is also influenced by the achievements of the institution. In general, these achievements are obtained from competition activities attended by students. In this case, the teacher is the party who plays an important role in giving guidance to their students. To improve students 'academic competencies, teachers, in accordance with their duties, have prepared good teaching, pay attention to the diversity of students' characteristics, be democratic in developing strategies, and pay attention to the interests and needs of students, in order to produce a maximum learning experience so that students can receive lessons well.

3. Evaluation in Handayani PAUD Quality Improvement Planning

In government regulation, No. 13 of 2007 stated that managers must have supervision competencies. That is, managers must plan academic supervision programs, carry out supervision of teachers, and follow up the results of supervision in order to improve teacher professionalism. In other words, the manager is responsible for empowering educators well in order to improve the quality of education in the institution he leads.

Institutional quality improvement is also related to the achievements of students. And students who excel are certainly closely related to a teacher who has educated him in school, besides of course the support provided by parents. In this case, the teacher at Handayani PAUD has planned and implemented the learning and conducted an evaluation of students during the teaching and learning process and at the end of the learning.

As stipulated in the Teacher Competency Standards that teachers have 7 functions, namely: as educators, as instructors, as mentors, as trainers, as program developers, as program managers and as professionals. Especially as a teacher, the teacher is tasked with planning learning, implementing learning that educates and assesses learning processes and outcomes.

However, during observations and interviews with managers or other personnel in the institution, there is no mention of the role of PAUD supervisors in evaluating the quality of institutions. PAUD supervisors certainly can also play a role in providing supervision, guidance, and evaluation regarding the improvement of the quality of the institution. As explained by Veithzal Rivai and Sylviana Murni (2009: 848) that the supervisory task is: (1) compiling and implementing annual activity guidelines, (2) guiding the implementation of the curriculum, (3) guiding technical personnel, (4) guiding administration, (5) guiding the use and care of school assets, (6) maintaining cooperative relationships with stakeholders, and (7) submitting results reports to carry out tasks.

The definition of supervision has been widely discussed by administrative and management experts. Bateman and Snell stated that supervision is an activity to direct individuals in achieving organizational goals. Whereas according to Robbins and Mary "Control it's a process of monitoring, comparing, and correcting work performance." While Luthans and Doh saw that supervision was "Controlling the process of measuring performance and taking action to ensure desires result" (Mukhneri Mukhtar, 37: 2013).

To get a good quality institution, it should be if all components are involved, including the supervisor. Principals, teachers, and supervisors need to increase their roles in improving the quality of institutions. A good supervisor can help with problems faced by both the principal and the teacher in the institution. Supervisors can help principals and teachers to carry out tasks according to their respective job descriptions.

It can be said that improving the quality of institutions can be started from qualified school supervisors. Quality supervisors will produce 
qualified teachers; qualified teachers will produce quality institutions and students; of qualified students will produce a quality society as well (Veithzal Rivai and Sylviana Murni, 78: 2009).

Therefore, it is important for managers to supervise supervision of the PAUD units they manage.

4. Supporting factors and obstacles to improving the quality of Handayani PAUD education

Based on the findings of the data obtained by the researchers it can be concluded that several factors that support the occurrence of quality improvement in Handayani PAUD include:

a. Purpose

Every activity or activity carried out by Handayani PAUD institutions is an encouragement to achieve the goals. The aim to be achieved by Handayani Early Childhood Education is for good quality education. It is able to bring PAUD Handayani into a B accredited PAUD for playgroup programs and kindergartens. Every institution that focuses on goals, all elements in Handayani PAUD institutions will be encouraged and do their best in guiding and directing to achieve goals.

b. Principal/manager

The principal/manager as the principal of the school or institution has an important role in making good quality improvement efforts related to input, process, and output in education. Professional leaders will target the material to be more active and diligent in achieving aims. It is manifested in the head of the school. Handayani PAUD managers who have become professional leaders in work. Because the headmaster PAUD Handayani conducts direct monitoring of his subordinates so that the performance of teachers and administrative staff can be evaluated directly.

c. Support and participation of educators and education personnel

In the institution, it can realize management from planning to improve the quality of the institution. With the support and participation of educators and education staff in the institution, the programs that have been planned will be possible. Even so, the manager must continue to oversee the implementation of the planning of all programs that have been prepared together with the parties concerned.

The manager also includes educators and education staff in institutions in training and training to improve their respective competencies. An educator is always supposed to improve his competence so that he can become a qualified educator and produce qualified students.

d. Administrative Staff

Administrative staff who act according to standard operating procedures in the office by having a work ethic that is friendly, polite, and communicates well. Professional and responsible for his work.

e. Other resources (funds, curriculum, facilities, and infrastructure)

In order to achieve the quality of education, the school/institution improves the existing resources such as the Operational Operational Assistance Fund (BOP), the KBM guidelines based on the curriculum, the improvement of institutional facilities and infrastructure so that the children and Handayani PAUD work units can utilize effectively and efficiently. Completeness of facilities and infrastructure is also a factor of how Handayani PAUD is able to compete with good quality.

f. A conducive environment

A conducive, safe and comfortable environment is one of the reasons for parents to send their children to Handayani PAUD. A clean environment and the presence of green plants that are driving factors for Handayani PAUD's coolness. Besides that, a close relationship and a sense of kinship between teachers, parents, as well as school residents in Handayani PAUD institutions are things that are always applied by Handayani PAUD, so there are no gaps with each other.

While the inhibiting factors found by researchers are parents who want their children to learn calistung material as soon as possible and some of the parents consider the weight of the monthly money charged by the institution. Another inhibiting factor is educators and education personnel who do not have an appropriate educational background. Educators are also less creative in using the media and APE that are available at the institution. In addition, there are several APE whose numbers do not correspond to the number of students in the institution.

Mortimore (Hendyat Soetopo, 94: 2005) suggests several factors that need to be considered in improving the quality of educational institutions, namely:

a. Positive and strong leadership. A leader who has strong character and commitment can give a good example to his subordinates.

b. High expectations. High expectations can be expressed in planning and then applied to be realized together.

c. Monitor student progress. This monitoring activity can be carried out by the teacher by evaluating during the learning process and at the end of the learning process.

d. Student responsibility and involvement in life in school. Education will be quality and trusted by the community if it produces graduates who are responsible, disciplined, creative and qualified.

e. Intensive and Prizes. This intensive needs to be applied to increase students' motivation and discipline in the learning process. 
f. Parental involvement in school life. The success of a student certainly cannot happen easily without the support of his parents.

g. Consistent planning and approach. A program will be carried out well and successfully if done with varied approaches and carried out consistently.

5. Efforts are made to overcome obstacles found in the process of implementing PAUD quality improvement planning.

Faced with several obstacles in the process of implementing quality improvement planned by the institution, the manager does several things as an effort to overcome these obstacles. For example, when parents demand that teachers teach calistung to their children, the manager approaches the parents directly. The manager explained that early childhood learns through playing, and there are things that need to be given to children before they learn to read, write and count.

In id.theasianparent.com explained there are several main concepts that need to be taught to children according to their age and development. The first is to recognize letters and sounds, study colors, shapes, objects and recognize numbers. Then learn to cut, stick and draw, and socialize. Learning to can be in the form of learning to share, working together, waiting in line, and acting with friends.

The basic things that need to be instilled in this early childhood besides being taught by the teacher at school also need to be known by parents. Parents can train and play with children at home to reinforce what the teacher has given at school. Therefore, there needs to be a good relationship between institutions and parents.

This agency manager is also aware of this. Therefore the manager also plans to hold a parenting program in the institution's environment. Parenting is an educational effort carried out by the family by utilizing the resources available in the family and the environment in the form of independent learning activities (paud-anakbermainbelajar.blogspot.com). The general purpose of the parenting program is to invite parents to provide the best for their children jointly. And the specific purpose of this program is to increase the knowledge and skills of parents in carrying out care, care, and education of children in their own families with good foundations.

With a good communication relationship and the same expectations between family and institution, it is very likely that early childhood can develop optimally. It can also unite the character education taught at school and home. This program will form good cooperation and mutual support between families and schools. But to form this program several things need to be prepared, namely; identify parental needs, form committees, create job desk, compile programs, schedule activities, identify potential and supporting partners, implement programs, and conduct evaluations.

Related to the problem of educators and education personnel who do not have an appropriate educational background, in the meantime, the manager has tried to involve educators and education personnel in appropriate training and training. It is to support increased competence in carrying out their duties at the institution. Besides that, the manager revealed that the institution would continue to strive to have educators and educators with an appropriate educational background, as one of the factors that can add more value to institutions in improving the quality of PAUD education.

\section{CONCLUSIONS AND SUGGESTIONS}

\section{A. Conclusions}

Based on the results of the study and the discussion that has been presented related to the management of the quality improvement planning of Handayani Early Childhood Education in the City of Pontianak can draw the following conclusions:

1. Quality improvement planning in Handayani PAUD is carried out by first making program preparation such as PAUD work plans prepared with committees, educators and education personnel based on evaluation results in the previous school year. This work plan was then socialized to parents. Then for educators can arrange the learning tools based on the curriculum that has been established, prepare learning plans, implement learning plans, and conduct evaluations. Educators should be able to enrich their knowledge about teaching methods and then apply them in teaching and learning activities, creatively using the media and APE that are available and make simple media that do not yet use objects or things that exist around the environment. And finally, for administrative staff whose job is to manage and compile matters relating to administration and information and communication technology. The administrative staff is also responsible for the management of goods and management of institutional facilities and infrastructure.

2. Management of quality improvement of PAUD conducted by institutions to improve the quality of institutions is by first disseminating work plans to parents of students. Then provide motivation, good communication, guidance, including training or appropriate training and continuous monitoring or evaluation of educators and education personnel to create a positive and conducive work atmosphere.

3. Evaluation in the planning of quality improvement is carried out by the manager by periodically supervising and continuing, both for the education staff as well as the administrative 
staff. In addition, educators also evaluate students and their students' learning outcomes. Student learning outcomes or achievements and quality of graduates are one component that the community sees in assessing the quality of an institution. Therefore educators need to plan improvements based on evaluations obtained from learning outcomes and the achievements of their students. However, neither the manager nor other personnel in the institution mentions the involvement of supervisors in terms of evaluation. Whereas supervisors should also be able to play a role in providing guidance and supervision on the running of PAUD quality improvement programs.

4. Supporting and inhibiting factors in the management of quality improvement in Handayani PAUD education.

a. The supporting factors are as follows: a) the goals of the institution to improve the quality of education, b) the principal / professional manager, c) support and participation of educators and education personnel. d) administrative personnel, e) other resources (funding, curriculum, facilities, and infrastructure), f) parenting program g) a conducive environment and support this cooperation is possible all the programs that have been developed to improve the quality of institutions.

b. While the inhibiting factors found in the effort to improve this quality are a) parents of students who want their sons and daughters to be given calistung material immediately. b) educational background of educational staff and education that are not appropriate. c) educators who are less creative in using the media and learning methods.

Efforts made to overcome the obstacles found in the quality improvement process of this institution include: a) the manager approaches directly to parents of students to provide explanations and understanding of things that must be given to students in accordance with the age of students, that there are other things that must be learned by learners before they receive the material calistung, b) looking for educators who have the educational background that is appropriate, while it continues to provide motivation and guidance also includes educators in the educational and training and training that can improve their competence. c) provide guidance and motivation to educators to enrich insight into learning methods that can be used in teaching and learning activities as well as more varied ways of using APE or available media. d) the manager plans to hold a parenting program in the future to create a common vision and mission as well as good cooperation between institutions and parents of students.

B. Suggestions
Based on the research findings related to the management of quality improvement in Handayani PAUD Pontianak City, the researchers submitted the following suggestions:

1. In the management of Handayani PAUD quality improvement planning, the role of the teacher as one of the parties that are directly related to students is expected to improve the skills and knowledge of early childhood education further, both the character of students, the use of media and diverse learning methods, so that they can educate and guide their students to become individuals with better character and competence. In addition, it is also to be a teacher who always has good enthusiasm and dedication to his work.

2. Manager

For principals to always provide motivation and good examples in implementing and supervising the running of institutional programs. A quality institution can be seen from the continuous improvement of management, as well as the improvement of employees, and the leadership and supervision that is at first, and quality supervision.

3. Education Personnel

For educational staff in institutions to be able to continue to support and jointly run programs that have been planned by the institution. Always be disciplined and maintain good relationships with colleagues, and have high enthusiasm and dedication to their work. Besides that, it is more concerned with the welfare of educators and education personnel and always prioritizes togetherness in PAUD units.

4. Administrative Staff

As administrative and management personnel act in accordance with the standard operating procedures that exist in the office and are responsible for the work that has been given.

\section{REFERENCES}

Acetylena, S. 2018. Pendidikan karakter Ki Hajar Dewantara. Madani.

Ardy Wiyani, N. 2014. Mengelola dan Mengembangkan Kecerdasan Sosial dan Emosi Anak Usia Dini. Yogyakarta: ArRuzz media.

Departemen Pendidikan Nasional, 2005. Peraturan Pemerintah Nomor 19 Tahun 2005, tentang Standar Nasional Pendidikan, Jakarta: Depdiknas.

Ma'mur Asmani, J.2015. Panduan Praktir manajemen Mutu Guru PAUD. Yogyakarta. DIVA Pres.

Maswardi M A dan Y. 2016. Manajemen Mutu Aplikasi dalam bidang Pendidikan. Media Akademi 
Hasan, M. 2012. Pendidikan Anak Usia Dini. Diva Perss.

Mukhtar, Mukheri. 2013. Pengawasan Pendidikan. BPJM Press. Jakarta.

Robbins, S.P dan Coulter, M. 2016. Management. Pearson Education. England.

Sugiyono. 2014. Metode Penelitian Kombinasi (Mixed Methods). Bandung: CV Alfabeta.

Suyadi. 2013. Strategi Pembelajaran Pendidikan Karakter.Bandung. PT Rosdakarya.

Undang-undang No. 20 tahun 2003, tentang Sistem Pendidikan Nasional.

Veithzal, R dan Sylviana, M. 2009. Education Managemen. Jakarta: Rajawali Pers. 